\title{
An Assessment of Public Works Programmes as a Poverty Reduction Strategy for Rural Zimbabwe: A Study on Chivi District
}

\author{
Mr. Lungisani Moyo \\ Department of Communication, University of Fort Hare \\ Email: lungie06@gmail.com \\ Dr. Osunkunle O. Oluyinka \\ Department of Communication, University of Fort Hare \\ Email: oosunkunle@ufh.ac.za \\ Mr. Kevin Onyenankeya \\ Department of Communication, University of Fort Hare \\ Email:nkenyakev@yahoo.com
}

Doi:10.5901/mjss.2014.v5n23p1739

\begin{abstract}
With the progression of the new millennium, a new socio-economic order has taken charge in most developing countries, unfavourable to the well-being of the less economically advantaged populations. Seemingly, Zimbabwe was not an exception to this development. Increasing concerns have been expressed about the effects of the several interventions aimed at poverty reduction in Zimbabwe, both from within and outside the country. The programmes and projects that have been devised to address poverty nationally and at local levels since 1980 have allocated vast amounts of resources and funding to different projects and initiatives. The nature of these initiatives have not demonstrated huge and resounding successes mostly because there have been serious shortcomings in their conceptualization and implementation. Based on the social development theory that believes that the human being should be the centre of development, this paper conceived poverty as deprivation of means of securing necessities in life. This study focused on assessing why the contribution of Food-for-work and Cash-for-work (public works) programmes towards reducing vulnerability of households to the problems of food deprivation, unemployment, and social exclusion in making important decisions in life has not produced resounding results. From the discussions held it was established that, poverty in the Chivi District is strongly linked to a failure of productive agriculture and exclusion from formal or urban wage employment. The main conclusions are that the public works programme has neither brought all the benefits its proponents expected, nor negatively affected the society as badly as critics of the programme might have believed.
\end{abstract}

Keywords: Poverty, food-for-work, cash-for-work, public works

\section{Introduction}

The world confronts challenges in rural development as it tries to deal with the issue of poverty. It is of utmost importance to note that, the world's poor people dwell in the rural areas, and it seems the situation will remain so as long as there is a pro-urban bias in most countries' development strategies and their allocation of public investment funding (World Bank, 2003:2). Although the world has been optimistic about rural poverty reduction, the World Bank statistical revelations predict that by 2015 more than 600 million people will be trapped in poverty mostly in sub-Saharan Africa (World Bank, 2006:v).

In a bid to reduce this, the concept of public works was adopted (alongside other strategies) by several countries world over. Zimbabwe also adopted the strategy in a bid to reduce the adverse effects of poverty in both the rural and urban areas. Public works conceptualises poverty from two standpoints, firstly as a deprivation of food, and, secondly as a collective deprivation of assets necessary to bring about socio-economic change.

However, rural people have little political power to influence public policy to attract public investment towards the rural areas. This is assumed to partly explain why the progress in improving standards of living remains very slow in spite of the adoption of several poverty reduction strategies. Herein, a study agenda was drawn from the fact that, amidst application of public works as a poverty reduction strategy in the Chivi District of Zimbabwe, poverty remains a major 
problem among these communities. The aim of the study was to investigate the successes and failures of public works programmes in the Chivi District in order to establish why poverty has not been significantly reduced.

The argument espoused herein is that, although Zimbabwe adopted public works to address poverty through cash benefits, food handouts and the creation of infrastructure that can spearhead development as a simulation from the rest of the world, the programmes had their own limitations and as such have not improved the situation of poor people in the Chivi District. Hence, the rural poor in Chivi still grapple with the challenges of poverty.

Zimbabwe's poverty situation can be best understood in the context of her colonial history. During the colonial era, the social, economic, and political atmosphere presented more economic and political benefits on whites as opposed to blacks. Land ownership laws offered only small and poor quality portions of land to Africans while whites were entitled to fertile land (Ranger, 1985:4-6). 'Native' education and employment opportunities were inferior to those of their white counterparts. These policies introduced great inequalities and perpetuated poverty among blacks. This culminated in a very long war of liberation and the subsequent attainment of independence in 1980.

In the 1990s, Zimbabwe entered into a phase of deep socio-economic recession. Chipika et.al. (2000:43) noted that, because of the socio-economic recession, real growth rate averaged less than three percent during the 1980-1990 periods. The private sector investment also receded to less than 10 percent of the Gross Domestic Product (GDP) from 1987-1989 and unemployment rose to unsustainable levels. In 1991, the country adopted the World Bank neo-liberal reforms under the name Economic Structural Adjustment Programme (ESAP). Although some groups of intellectuals argued that Zimbabwe did not adopt the foreign prescribed policy because of economic decline, it is apparent that seeds of an economic meltdown were beginning to germinate around the late 1980s. It was hoped that the Structural Adjustment Programme (SAP) would resolve problems that were associated with the growth of (GDP), incomes, and employment (Mwanza, 1999:1). Furthermore, the proponents of the SAP hoped to create a free market economy thereby, increasing investment.

Climatic factors, particularly drought, deepened the gravity of the problems, especially in 1992. The extension of the period of the reform that was originally planned to end in 1995 to beyond the year 2000 suggested that the government had realised no rapid results from the reform. The rigorous measures imposed by the ESAP, led to, inter alia, the massive retrenchment of skilled and unskilled labour and of the civil service, the closure of many manufacturing industries, general price increases, and the deterioration of social services. According to Sachikonye (1995:63) in the manufacturing industry, about 1600 workers were retrenched by Cone Textiles in October 1992 because of its liquidation. Many more faced retrenchment in various industries during this era. These factors, combined with the liberalisation of the economy, led to a rise in poverty levels and a reversal of the gains of independence in Zimbabwe.

Most of the workers retrenched during this period returned to the rural areas to add to the percentage of the poor population. Mwanza (1999:15) argues that before 1990, when the ESAP was adopted by Zimbabwe, poverty was too insignificant a problem to Zimbabwe to the effect that its extent is unknown before this period. Nevertheless, the adoption of the ESAP also exposed some major disjuncture between policy objectives and outcomes.

It can be argued that, while the public works policy speaks the same language with SAP, that is cost recovery and cutting government expenditure, SAP are more hostile to public works. The fate of public works after the adoption of SAP in 1991, therefore, hung precariously in the balance. This is because SAP stressed on the total disengagement of government from providing social services as well as funding public investment. However, in this case, the Government continued to host the Ministry of Public Works, which still runs some projects aimed at poverty reduction in both the urban and rural areas.

An intensification of public works programmes was seen in 2003 when a new statutory instrument was enacted which governed and regulated the operations of Non-Governmental Organizations in Zimbabwe. The Policy on NonGovernmental Organizations in Humanitarian and Development assistance stressed the need to integrate public works in all humanitarian assistance. It stressed that, no aid for the poor was to come as social welfare but people should be given development projects targeted at the construction of infrastructure as well as enhancing their life through public works (Government of Zimbabwe, July 2003:3).

It is, therefore, against this background that this study had to be carried out. The study investigated the success of public works in reducing the effects of poverty in the Chivi District's five wards. The study tried to find out if what public works aims to address as poverty is the actual poverty challenge that prevails in the rural areas. Since decentralization which is the policy that houses public works does not fully empower the poor to think and do development, a question remains unanswered that is; can rural poverty be successfully alleviated using programmes that are conceived in isolation from the people that are the intended beneficiaries? 


\section{Literature Review}

The world admits that efforts to date have not been successful in eliminating poverty from the face of the earth. It is from these foundations that this study becomes a worthwhile study. This study does not break new grounds but develops from the works of previous scholars like Haines, Kothari, De Beers, and Swanepoel. Here in this study hopes to show that the modernisation and neo-liberal principles adopted by public works reduce the efficacy of the programmes in the reduction of poverty.

Discussions on theories do not form a major part of this study; however, it is indispensable to take cognisance of the conventional debates in this regard to be able to put social development in context. No claim is made towards the building of new theories but social development will be investigated as a possible theoretical approach for the development of Zimbabwe's rural poor.

\subsection{Modernisation Theory}

Some leading conventional literature on development seems to indicate that, all nations are characterised by modernisation as their ideological model for development. This theory was very popular in the 1950s and 1960s. It viewed development as an evolutionary process where societies go from simple to complex institutional structure. According to Haines (2000: 32), modernisation assumes that all societies tend to follow one route to development. Societies not yet developed are yet to pass through stages passed by the developed world.

According to this approach, the so-called "underdeveloped" communities can achieve the same status as developed countries if they would accept modernisation as a goal. It was assumed that developing nations would transform faster than Europe did because of the direct introduction of education, health care, and technology. To the developing nations, modernisation promised a guided transition towards a developed industrial society (Haines, 2000: 32). In this regard, development is seen as a global process aimed at reproducing the image of the highly developed societies.

\subsubsection{Critique of Modernisation}

Development strategies conceived in the framework of the modernisation theory put more emphasis on industrialisation and economic growth. They also call for progressively more centralised planning and control over the allocation of resources. Provision of infrastructure and institutions to manage this progress according to a western model is emphasised (Gabriel, 1991:1). Notwithstanding the existence of the idea that, increases in national income eventually lead to the solution of social problems, the experience of the past decades proved this belief to be a mistaken one.

Modernisation theory implies that the standard of living is likely to go up as poor countries industrialise. Industrialisation, has however, had some negative impact on the lives of rural women and children who are left by men to fend for themselves. As modernisation encroaches, the traditional stand of the extended family weakens and extends the responsibility to neighbours. Women who are abandoned or divorced find difficulty to fend for themselves. This has led to an increase in the levels of all forms of poverty.

While there is no easy answer to the question of how poverty can be alleviated, various studies have provided a strong indication about the role of overall economic growth in reducing poverty. Modernisation tends to liberate women from domestic confinement as they take up jobs outside the home. Women also gain some dignity as they are accorded freedoms and opportunities given to everyone. In Asia, for example, the countries that achieved notable success in poverty reduction (namely, the People's Republic of China (PRC), Indonesia, the Republic of Korea, Malaysia, and Thailand) are also the ones that attained high rates of gross domestic product (GDP) growth. It must be noted, however, that a high rate of economic growth is only a necessary condition, not a sufficient criterion in itself, for reducing poverty.

\subsection{Basic Needs Approach}

After the realisation, that economic development would not eliminate underdevelopment, and that the discrepancy between rich and poor had in fact escalated, it was propagated that the real issue was not the resources, but their availability to all. A school of thought developed which argued that human societies were not to follow luxurious standards for all, and that if the focus was on fulfilling "basic needs" of all human beings, the world still has enough resources to meet the needs of all (Kothari, 1993: 12). The approach was named 'basic needs' and it gained currency in the later 1970s. 
The basic needs theory is grounded in the idea of shifting from a grand theory to approaches that are more 'practical' aimed directly at reduction of poverty through social services such as education, health and welfare programmes, (Haines, 2000:32). Basic needs theorists generally argue that the mainstream theories fail to adequately consider human needs and structural impediments inherent in developing countries' economies (Seidman and Ohiorhenuan, 1992:23). The basic needs approach insists that each person must have the minimum requirements for existence. The International Labour Organization (ILO) identified the following as categories of basic needs:

basic personal consumption: food ,shelter and clothing, access to essential services: clean water, sanitation, education, transport and health care, access to paid employment, and qualitative needs: healthy and safe environments and ability to participate in decision-making.

(Adapted from Hunt, D.1989: 256)

The approach suggests that the development of the community should begin with the rise of the people at grass roots level towards their own emancipation. Basic needs should be identified for each community in recognition of the fact that the priority of needs differ according to the people's socio-cultural conditions. The theory concludes that, at every stage of development, local people do know what their needs are, and they can be relied upon to determine their own priorities of development and then work at them. This approach was the first to be people-centred, contrary to the previous economically centred approaches. As such, it introduced development approaches in which people at grass roots level would become the main actors in development; and can be seen as a forerunner of the people-centred approaches that were to follow (De Beer and Swanepoel, 1998:8).

\subsubsection{Critique of Basic Needs}

The main goal of the basic needs approach was to provide the basic needs of the poor within the shortest possible period. The focus of basic needs on grass roots participation in identifying basic needs and wealth redistribution are its strong points. The approach is also regarded with respect on the basis of the fact that meeting the needs of the poor would not only help reduce poverty, but also improve on the education and skills levels of the population with the concomitant potential for contributing to greater economic growth and development.

It does however appear that while the Basic needs Approach focuses on what it wants to achieve, namely meeting the basic needs of the people, it never really developed a methodology on how this should be achieved. The approach also focuses on improving public services, which are financially demanding, and in most cases, governments are not willing to bear the burden of. The approach's focus on small-scale activities has also been criticised as a brake to rapid economic growth and has been viewed as a method of continuing to trap developing countries in primary production. According to De Beer \& Swanepoel, (1998:5) basic needs consequently lost its appeal in the early 1980s as a separate approach to ending poverty and enhancing human potential towards the development of poor countries.

\subsection{Neo-Liberalism}

A new ideology, neo-liberalism began to take charge and enjoyed increasing popularity from the mid-1970s. According to Haines (2000: 48-49), the global economic recessions of the early 1980s as well as rising debt were decisive of this policy shift in the developing world. The seminal neo-liberal thesis on Africa was first enshrined in the 1981 annual World Bank report on Sub-Saharan Africa, when the role of the state in development was first questioned. The main points of neo-liberalism according to Martinez and Garcia (2000) include:

the rule of the market liberating "free" enterprise or private enterprise from any bonds imposed by the government (the state) no matter how much social damage this causes. It also calls for no more price controls. Concisely, total freedom of movement for capital, goods, and services and an unregulated market are perceived as the best way to increase economic growth, which will ultimately benefit everyone through trickling down effects.

\subsubsection{Critique of Neo-liberalism}

Although the objective of eliminating the public good by adopting neo-liberal reforms is one of the main ideas of neoliberalism preached around the world, this does not mean that the neo-liberals are not aware that poverty can be reduced by the creation of public resources. A World Bank publication reads, "Anti poverty, programmes will not succeed unless delivery systems are adjusted to deliver more public-resources where the need is greatest, to increase transparency and 
accountability to beneficiaries, and to build capacities of the poor communities to help themselves" (Word Bank, 2000:101).

It is so surprising to get such a comment from the World Bank since around the world; powerful financial institutions like the International Monetary Fund (IMF), the World Bank, and the Inter-American Development Bank have imposed neo-liberalism. The influence of these giant organisations is more apparent when viewed in the Structural Adjustment Programmes era. SAPs advocated for cost recovery and cutting government expenditure, SAPs, are more hostile to programmes like public works for they increase government expenditure. SAPs' neo-liberal reforms attack the concept of the public good leaving the fate of public works after its adoption hanging precariously in the balance. Theoretically, after SAPs, there must be no public works since the neo-liberals stressed on the total disengagement of the state from providing social services, as well as funding public investment.

Schuurman (1993a) noted that, Neo-liberalism destroys welfare programmes and cuts back on social programmes. The ideology favours a minority while it disadvantages the masses. A follow up on neo-liberalism leaves scholars doubtful of who should be players in rural development as it removes the idea of collective ownership of assets and state investment in public institutions. According to neo-liberalism, the state should primarily make an effort to lower the monetary shortfall through devaluation, the deregulation of prices and decreasing state subsidies. Limiting the role of the state, creating a liberal economy and a strict monetary policy according to the guidelines of the International Monetary Fund (IMF) and the World Bank are the major policy options in many developing countries. Neo-liberalism principally discards the idea that the state should represent the value of common unity through which wealth is redistributed through income support and social services.

From the above discussions of a number of prominent development theories, it appears that a major problem was that although development is supposed to be all about people, a top-down technocratic approach was followed. This approach treats people and cultures as abstract concepts, statistical figures to be moved up and down in the charts of "progress".

Ake (1996) reviews the "...years in which Africa was pre-occupied with development..." and sees "meagre returns." Ake draws the conclusion that, a plethora of factors has been militating against this development. Among these factors, he mentions poor planning, incompetent management, and inappropriate policies (Ake, 1996:1-3). Todaro (1989:91-92) supports this assertion and explains the development dilemma of Africa by using a false paradigm model. Africa gets "...inappropriate expert advice provided by well meaning often-uninformed advisers from the developed world. ... the advice leads to inappropriate policies." Pre-packaged solutions come from abroad with total disregard for the sociocultural reality of the recipient society.

The researcher believes that while underdevelopment is a global problem, there are no global solutions to underdevelopment.

\subsection{Towards the Adoption of a People-centred Development Paradigm}

It has been observed that the existing approach to development was conceived at two levels, one level has to do with the fulfilling of the minimum needs of the people by removing the source of poverty and marginalisation. The other approach focused on following the path of going for all the latest technologies, catching up with industrialised countries (modernisation). Contrary to this trend in development, the focus of this investigation is directed towards people-centred development. Commitment towards this avenue was shown at the world summit for social development held in Denmark in 1995. According to UNDP (1998:4), governments undertook to pursue a programme of action embracing the following:

Putting the people at the centre of development; uprooting poverty in the shortest possible time; promoting employment for all; and integrating groups that are still excluded.

This study advocates for an adaptive approach to development and poverty issues in development (social development).

As development programmes worldwide were being reviewed, many of the basic tenets of development theory became questionable. It is recognised that these programmes generally failed to help reduce poverty and underdevelopment in any significant way. This recognition caused a hot pursuit for alternative approaches. There was a major shift in the directions and priorities of development theories.

The notion that development aims primarily at maximising gains in the gross national product has been deeply criticised, for example, Cheema and Rondinelli, (1983: 12) posit that: 
Planners and policy makers began to recognise that development requires a basic transformation in social, economic, and political structures that enables poor people to help themselves to increase their productivity and incomes.... poverty would not be ameliorated "automatically" through trickle down and spread effects.

The idea of social development that came as a counter theory to the mainstream theories in Africa was a brainchild of the Organisation of African Unity (OAU). The Union came up with a plan of action in 1981 named the Lagos Plan of Action for the Economic Development of Africa. The plan featured the integration of social and economic development, and sought to improve in general, living standards through focusing predominantly on the rural areas and uncared-for regions. Elementary to the success of the philosophy was the mobilisation of labour and skills for efficient service in health, education, and other social sectors (Ndongko, 1991:26).

The poor were identified as the main beneficiaries of development programmes and their needs and characteristics were taken into consideration. Social development, which emerged in the developing world, embodies the viewpoint of a positive, humane, people-oriented development in society, centrally concerned with social justice and equitable distribution of resources (Midgley, 1995: 25

For development to be sustainable it requires the active involvement of people, the beneficiaries themselves, in the design and implementation of activities intended to improve their welfare. While arguing for social development (Ndongko, 1991:26-32) proposes that:

...reaching social development requires the overcoming of poverty, unemployment and glaring disparities in income and wealth. Such an approach requires the focus to be redirected from re-active to pro-active intervention, with its emphasis on prevention, resource building, and education.

The empowerment of people to take increasing charge of their own development is the key element, combined with a clear understanding of environmental constraints and of requirements to meet basic needs (Haines, 2000: 33). As opposed to its predecessors, the social development strategy emphasises the opportunity to participate, rather than giving more aid towards the welfare of society. It has been realised that different countries, communities and people, would accept different development goals, according to their particular values and norms. For development goals to embrace the values and norms of a specific community, the members of that community have to own the decisionmaking process.

People must be central in the whole development process. They must be involved in a transformative process not just being where they are moving forward towards a future that they want. It is believed that poverty can only be removed by the substantial empowerment of people, individually and in groupings. What is needed is social empowerment: to enable the people to acquire skills and capabilities that are basic to both their self-respect and to their political and social standing and bargaining capacity (Kothari, 1993: 72).

Social development is accepted as an approach directed on promoting a social condition of well-being and is characterised by involving the notion of growth and positive change, and seeks to integrate social and economic processes, as both are integral facets of development. It does not primarily deal with individuals by providing services or by treatment, but seeks to enhance the well-being of the population, and is therefore inclusive in scope (Midgley, 1995: 23). It seeks solutions to eradicate poverty and favours a wide variety of approaches and strategies because of its wide scope. However, the decisive objective of social development is to bring about unrelenting improvement in the well-being of the individual, family, community, and society.

This study advocates for the adoption of the social development paradigm in sculpturing development policies and poverty reduction practices.

The theory argues that, impractical views exist of an alternative development grounded on small and localised efforts, based on mutual aid. It is further argued that, despite their impracticality, they can form a strong countervailing culture of development against the dominant modernisation and neo-liberal development theories (Kothari, 1993: 127).

It is necessary to accept that development efforts will have to face up to realities such as the decreasing role of the state in providing "safety nets" and a world-wide tendency that the poor become poorer as the rich become richer. Hence the need for a development model that has the capacity to generate methods for reducing poverty. The model should also strive towards developing human potential within the present order, rather than to counteract or to oppose the dominant trend of neo-liberalism. Social development has been viewed as harbouring such potential. 


\section{Research Methodology}

\subsection{Participants}

The population consists of sixty respondents drawn from five wards in the District due to the fact that, Household information is sensitive and most of the times treated as private and confidential; it was difficult to go about randomly selecting participants for the study. As a result, poor households were selected using snowball sampling where influential personal contacts were used by the researcher to facilitate access to the chosen participants. Graphs and charts were drawn during data analysis to illustrate some of the results gathered from the field and were generated through Microsoft excel.

\subsection{Instrument}

The instruments used in this study were self administered questionnaires, focus group discussions and face to face structured interviews. Due to financial constraints, 60 households from five wards were interviewed. Two communities were also jointly gathered for a focus group discussion. This was done to deal with the problem of individual household biases since the discussions also invited village heads, ward representatives, and chiefs.

\section{Findings and Discussion}

\subsection{Employment Creation}

Pfeffermann and Fields (2003:3) argued that, "more and better jobs offer the best opportunity for upward mobility in the lifetimes of the poor people and their children." This study also believes in the same idea hence the conclusion that employment creation is a strong pathway out of poverty given the absence of a belligerent capitalist exploitative drive.

During the focus group discussions, participants cited the issue of unemployment as one of the poverty challenges faced by the villagers. The study also established that the majority of those who categorised themselves as self-employed were engaged in agriculture related work. Some of them were involved in growing of vegetables and rearing of chickens. Some however, processed peanut butter. Despite the mentioning of income enhancement as a predominant reason for participating in food-for-work or cash-for-work projects, this study argues that from the available data unemployment is the major factor that led the participants to take up jobs in public works projects.

\subsection{Employment Statuses of Interviewees}

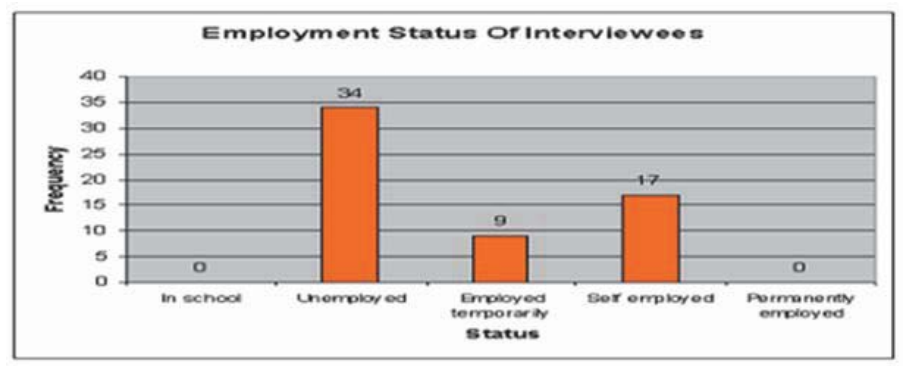

Figure 1. Employment Statuses of Interviewees

The sixty respondents sampled in this study were asked to state their employment status. Data from the questionnaires indicated that $56.7 \%$ were unemployed. $15 \%$ were temporarily employed $28.3 \%$ were self-employed while no schoolchildren and permanently employed did not participate (hence $0 \%$ indication.)

This distribution was because the selection criteria used for the sampling of participants to the households included scouting for unemployed people who struggled for their daily supplies.

The unemployed seemed to have more time at their disposal to commit themselves to community programmes. However, the researcher concludes that, during the time that the household interviews were completed; only those people who did not go to work were found in the homes. This was mostly during the day. Nevertheless, this was believed 
not to stage-manage the outcome of the study.

\subsection{Social Exclusion}

In this study, social exclusion refers to the inability of individuals to take part fully in any social, political, and economic functioning of the society (Buvinic, 2004: 5). People need the opportunity to participate fully in the life of their community if they are to flourish and realise their potential. Nevertheless, certain groups in society are excluded from opportunities that are open to others because they are discriminated against based on their race, religion, gender, caste, age, disability, or other social identity. Relying on Gareth Thomas in the foreword to a Department for International Development Aid (DFIDA) Policy Paper," people who are excluded like this are not 'just like' the rest of the poor, only poorer".

The study shows that more women than men were involved in community-based public works. It appears that, this is because women were deliberately encouraged to actively partake in the formal work force As shown in the chart below, of the 60 participants who took part in the household interviews, 47 (78.3\%) were female and 13(21.7\%) were male.

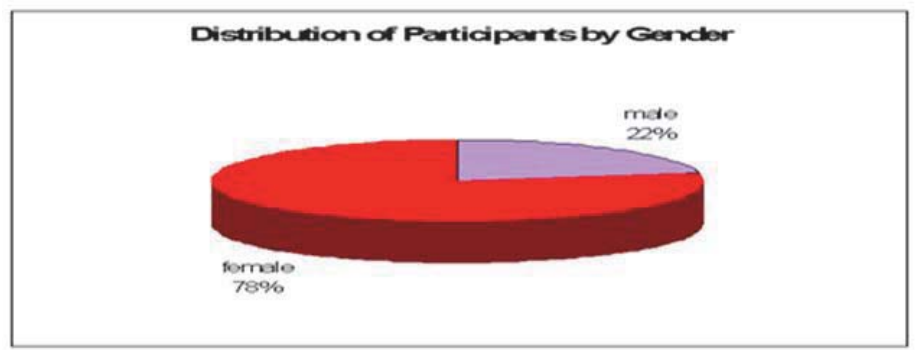

Figure 2. Distribution of Participants by Gender

The importance of providing work for women is emphasised by the remarks made by interviewees on the subject of the effect of seeing women working in eccentric roles. In the in-depth group discussion, comments were made that women work well in some cases better than the men do. Discussant four, a former councillor said that one of the new things that came out of the reservoir construction project in which he was part of the co-ordinating team was the message that

"most of the women know how to do men's jobs. You will not struggle and think because they are women they cannot push the wheelbarrow. I would even select more women than men because they do not quarrel a lot."

From both data collection experiences, the researcher learnt that, women made up an undisputable majority in public works projects. The researcher had a chance to interrogate in depth the reasons why women were or were not engaged in public works projects. The main factor, encountered in all the case studies, was the observation that the work activities, particularly the construction activities, were branded "men's work". Despite the promulgation and promotion of the doctrine of equity, the targeting of women converged with mixed feeling, promoted successfully by government in most cases, but simultaneously constrained by cultural bias within communities.

Regardless of this bias, this study concludes that public works in Chivi emancipated the position of women, and women were, therefore, not excluded in this respect. The study found that community-run projects gave sufficient priority to women. Their participation helps to break down unfairness. Despite bringing equity, the provision of income earning opportunities to women was believed to provide many benefits to household welfare, over and above the benefits that would be derived from giving men an equal opportunity.

\subsubsection{Educational Qualifications of Interviewees}

Another way in which social exclusion can be manifest is the discrimination of poor populations as per educational standards attained. In most cases, voices of the poorly educated are not heard and the spreading of opportunities is in most cases elitist. The following table shows the educational status of the people who participated in the household survey who claimed to have participated in public works projects. 
Table 1: Educational Qualification of Interviewees

\begin{tabular}{|l|c|}
\hline Educational Qualifications & Frequency \\
\hline Never went to school & 7 \\
\hline Primary & 38 \\
\hline Secondary & 11 \\
\hline Other & 4 \\
\hline
\end{tabular}

The table above shows that 7 (11.7\%) participants never went to school, 38 (63.3\%) had attained primary education, 11(18.3\%) had gone through their secondary school, and only 4(6.7\%) participants had gone above secondary education. It was, however, not specified which levels they had attained. This could mean advanced level graduates, certificate, degree, or diploma holders. Primary level graduates had the highest number of responses indicative of their keenness to participate in community programmes. It is possible that this generation came from the forty to forty-five age groups that predominantly participated in the interview.

The data set above helps to explain the reason why the majority of the participants in public works projects are unemployed formally as was shown by the data on employment statuses. It appears that, one's educational qualification determines the type of employment one gets. In Zimbabwe, it is difficult for primary school graduates to get formal employment opportunities. Opportunities are more open for them in agriculture and other informal jobs that demand less skill. While the lowly educated formed the majority of the participants in the programmes, it is very difficult to conclude whether this is a form of emancipation or exclusion.

The unemployed and lowly educated seem to have more time at their disposal to commit themselves to community programmes. A possible explanation favouring their participation could be that, because these people do not have qualifications to compete for gainful employment in the formal sector, they find public works attractive. It can be concluded that, public works programmes in the Chivi District did not exclude people based on education since no certificates were required to get the job. One only needed to be poor to qualify.

\subsubsection{Popular Participation}

An opponent to social exclusion is the concept of participation. It advocates for the recognition of every person as an important partner in development. Several development stakeholders in Zimbabwe pushed the frontiers of participation which emanates from the social development theory. The United Nations Economic Commission for Africa (UNECA) argues:

People's participation is the engine for launching the process of economic transformation; it is the motor for accelerating the process of development; it diffuses power...and encourages people to make full use of their talents. (The UN Economic Commission for Africa (ECA) Executive secretary, In Participatory Development: The Case of Zimbabwe, 1996)

As a sequel to this and other arguments, the researcher asked the respondents in the household questionnaire if public works projects gave them chance to participate in making important decisions about project choice in their community.

The results show that $86 \%$ testified that they participate in coming up with projects. A further $14 \%$ denied having done so. The dominating explanation was that they did not participate because the elite leadership would have already chosen projects for them. They however felt these leaders know better and it is their responsibility. On the cost of participation, the predominant problem cited was the lengthening of decision making process. Respondents stressed that participation is useful as it educates on future leadership, removes the chances of corruption, and brings projects that serve the majority and not the interests of a particular dominating group.

\subsection{Benefits of Public Works Projects}

It was a finding of this study that, although public works programmes have some shortcomings, they largely are associated with benefits warmly embraced by the rural beneficiaries. It appears that many rural people rely on the public works for both household incomes and household food source. In the household questionnaire survey, participants were asked to indicate their main sources of food and income. Below is a pie-chart showing the data for sources of income for the interviewees. 


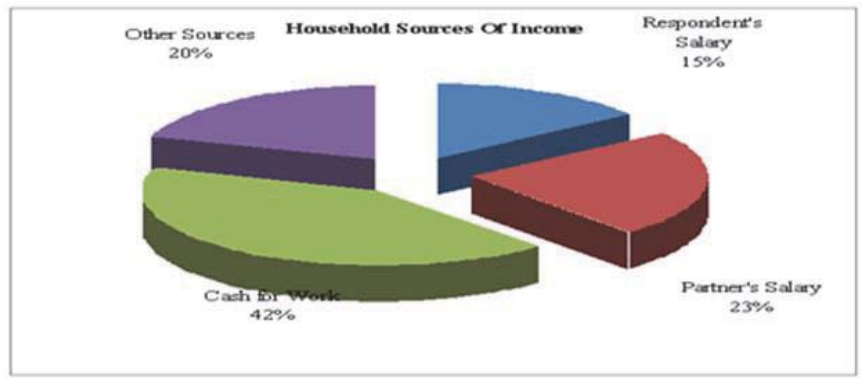

Figure 3. Sources of Income

It was found out that $42 \%$ of the participants relied on cash-for-work projects for their income. Similarly, $23 \%$ used their partner's salary. It was also found out that $15 \%$ used their own salary the other $20 \%$ responded that they used other sources. They specifically cited selling of garden produce like cabbages, tomatoes, and onions. Some of them cited that they relied on selling livestock and poultry. Of more interest, however, are those households relying on cash-for-works. These are vital in justifying one idea raised earlier in this study and other studies that public works projects are useful in enhancing household income.

\subsection{Sources of Food}

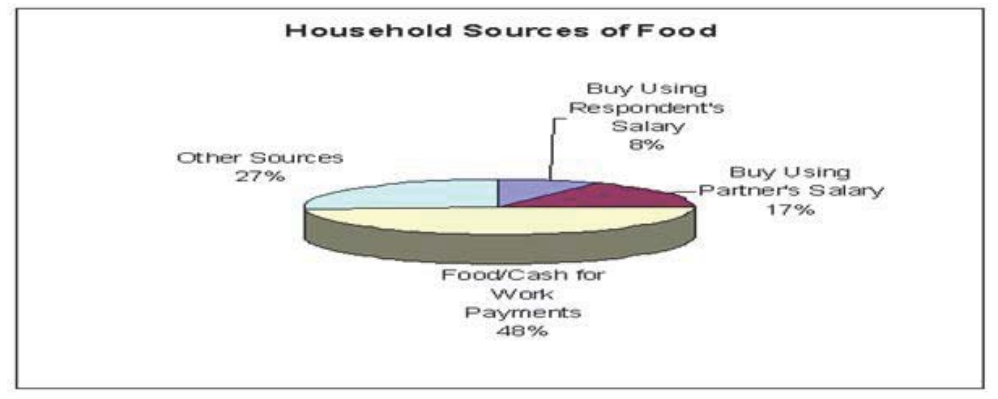

Figure 4: Sources of Food

The figure above shows the various sources that have been used by the sample households to secure their food. $48 \%$ of the respondents relied on public works payments for their food security. They used both food and cash payments to secure their food. Cash transfers from spouse's salaries accounted for $8 \%$ while $17 \%$ said they used salaries from their temporary employment. Other sources also accounted for $27 \%$. The other sources specified were similar to the sources for income save for relief food from government and non-governmental organisations.

Among the benefits listed in the questionnaires, it was echoed that public works projects are useful as a move towards poverty reduction as they increase household food security as well as cash inflow. The latter would allow beneficiaries to spend their incomes on any combination of food and other necessities of their choice. In the event, the cash-for-work scheme would guarantee minimum income to the most vulnerable while encouraging able-bodied individuals to be gainfully employed. It would also maintain the incentive to work and would eliminate the tendency to be continually aid dependent.

Both questionnaires and focus group discussion exposed mixed feelings concerning the benefits of the cash-forwork projects. The dominant idea was that, money from cash-for-work wages was spent for the overall benefit of the household. For the majority of beneficiary households the money went towards the purchase of household items such as salt, soap, clothes and other foodstuff such as cooking oil and dried fish (the latter leading to a diversification of diets). A number of households also invested in school fees for their children and the purchase of small livestock and were able to pay for health costs. Some few respondents talked about the rehabilitation of their homes. 


\subsection{Shortcomings of Public Works Employment Programmes}

The implementation of public works (food-for-work/cash-for-work) programmes in the Chivi District has not been immune to problems. In this study, the programmes have scored several positive outcomes amidst shortcomings. Although the programmes have been so instrumental towards the disbanding of the poverty reinforcing forces, it was a finding of this study that the scale of job creation was too low as compared to the levels of unemployment. Given that the number of participants hired in the programmes was limited, not every job seeker had an opportunity to be employed.

Most respondents expressed concern that the outstanding weakness of public works programmes is the scale of coverage of programmes. Many poor people were left out because the number of people needed for the work was limited. This is possibly an outcome of limited funding by the government. Although rotating participants covered this up, it only worked to a limited extent in assisting the poor. The study also noted that public works programmes allocate more to the projects and poor wages to the workers. It was also a finding of this study that the wages were low as compared to formal employment and other alternatives.

Many respondents raised a significant shortcoming of public works programmes; although the programmes were no longer a response to drought, they were seasonal and temporary. This implies that during the season when the projects are not operational the people will go back to their suffering and poverty. Most of the respondents expressed concern that public works had failed them on the part that it had failed to provide permanent jobs for them. There is generally a feeling that someone permanently employed is better off as compared to seasonally employed workers.

Apart from this, where food is used as payment, the participants complained that, the normal food payments are packets of maize-meal and beans. These people having no other income-generating projects find it difficult to get essentials as cooking oil, salt, and sugar. Thus, food payments have been criticised for lack of diversity in the foodstuffs. Some respondents also complained that where food is used as payment it takes long to be paid. This is possibly resulting from the logistical problems involved in organising the carrying of food around to the payment points.

Another weakness that was mentioned by the respondents was the inability of projects to continue after the end of the major programmes. Some micro-irrigation projects kick-start after creation of the necessary infrastructure but are neglected due to insufficient monitoring. The sustainability of the projects is then jeopardised. This then translates to no improvements as far as the deprivation situation is concerned.

\section{Concluding Remarks}

It can be concluded that, there are positive outcomes of the projects underscored throughout the study. Women were the main beneficiaries to these programmes as outlined in the findings. This was hailed as it promotes a culture of gender sensitivity. Generally, providing work for rural women has seen more benefits trickling into the households as compared to providing work for men. This is because most of the income is used for household use, which rarely occurs with most men who reduce their families to poverty by using the money on beer. The involvement and participation of women in the decision-making process has also been instrumental, as it has seen the suggestion of very useful projects. Infrastructure like village tracks and water weirs have helped to reduce the day-to-day hardships faced by these women and their communities at large.

While the public works programmes were hailed for the positive outcomes, it appears they are burdened with a load of negative outcomes as well. Of the outstanding negative outcomes, public works programmes have been criticised of micro focusing. Few people end up benefiting from the programmes, which pay little dividends. The reduction of food payments to mere tokens of appreciation has been defended as a targeting method to encourage self-selection and discourage the well to do from entering the programmes.

The above means that, only those in need end up participating. This increases poverty as the people will spend valuable time on a poorly paying job that consumes their time, which could be utilised in other activities that can increase their incomes. However, this reduction in the amounts paid off to individuals has been praised as it increases the number of participants in the programmes. This does not reduce poverty but equalises poverty with every person having an equal share with the other while remaining deprived.

It was also realised that no long-term employment has been generated and no effort towards doing this has been exerted. It was learnt that there is too little or no training that is associated with the programmes hence no building of capacity to get formally employed. This was concluded to be one reason why the people of Chivi remain deprived of employment. They are technically handicapped and programmes do little to foster their emancipation.

Poverty persists in the district because public works aims at curing symptoms of poverty. There is no effort at transforming the present conditions but emphasis is laid on improving the situation, which ends up in an equalisation of 
poverty among the poor communities. This means that poverty remains in place but with little inequalities if the poor people are compared.

Many of the projects and assets are neglected as soon as the programme directors leave. Funding also stops coming towards the projects. This has been associated with politicisation of programmes where projects come as campaign tools. After elections, they disappear. In this respect, there is need for self-regenerating and self-financing projects. It can therefore be concluded that although the public works programmes have not been significantly active at reducing some effects of poverty in the study district, they were also instrumental as they brought some useful outcomes.

\section{References}

African Centre For Applied Research and Training in Social Development

(ACARTSOD) (1980), Report of the Expert Group Meeting on the African Centre for Applied Research and Training in Social Development (Tripoli).

Ake, Claude (1996) Democracy and Development in Africa. Washington D.C: The Brookings Institution.

Cheema Sheeber.G and Rondinelli Dennis. A. (eds) (1983)." Implementing Decentralization Policies" in Decentralization and Development: Policy Implementation in Developing Countries. Beverly Hills, California: Sage Publications.

Chipika, Jesimen. T, Chibanda Stanford, Kadenge Phineas. G, (2000) Effects of Structural Adjustment in Southern Africa: the Case of Zimbabwe's Manufacturing Sector During Phase 1 Of ESAP: 1991-1995. Harare: SAPES.

Dashwood, Hevina.S. (2000) The Political Economy of Transformation. Toronto: University of Toronto Press.

De Beer, Frik. and Swanepoel, Hennie. (2000) Introduction to Development Studies. Cape Town: Oxford University Press Southern Africa.

Gabriel, Tom. (1991). The Human Factor in Rural Development. London: Belhaven.

Government of Zimbabwe (July 2003) "Policy on operations on Non-Governmental Organisations in humanitarian and development assistance in Zimbabwe" Ministry of Public Service, Labour and Social Welfare: Available on: http//www.sarpn.org.za/documents/ d0000520/index.php: Accessed July 2008

Haines, R. (2000). Development theory. In F. de Beer \& H. Swanepoel (Eds.), Introduction to development studies (pp. 31-58). New York: Oxford University Press.

Hunt, D (1989) Economic Theories of Development: An Analysis of Competing Paradigms. London: Harvester Wheatsheaf.

Jacobs, Garry and Asokan N., (1999) "Towards a Comprehensive Theory of Social Development" in: Human Choice, USA: world Academy of Art \& Science.

Kothari, Ranjini (1993) Poverty Human Consciousness and the Amnesia of Development, London: Zed books.

Midgley, J. 1995: Social development: The developmental perspective in social welfare. Thousand Oaks, CA: Sage

Mwanza, Allast (1999) Social Policy in an Economy under Stress: The case of Zimbabwe. Harare: SAPES Books.

Ndongko, T.M (1991) "The Lagos Plan and Social Development in Central Africa: an Evaluation" in Mohammed, Duri (ed.) Social Development in Africa: Strategies, Policies and Programmes after the Lagos Plan. England: Hans Zell Publishers

Ranger, Terrence. 0 (1985) Peasant Consciousness and Guerrilla War in Zimbabwe. London: James Currey.

Rondinelli, Dennis. A. (1993) Development Projects as Policy Experiments: an Adaptive Approach to Development Administration. London: Routledge.

Sachikonye, Lloyd "Industrial relations and labour relations under ESAP in Zimbabwe" in

Gibbon Peter (e.d) (1995) Structural Adjustment and the Working poor in Zimbabwe. Uppsala :Nordic Africa Institute.

Schuurman, Frans J. (e.d). (1993a) Beyond the Impasse: New Directions in Development Theory. London: Zed.

Seidman, Ann and Anang, Ohiorhenuan (eds.) (1992) Twenty first century Africa: Towards a New Vision of Self-Sustainable Development. New Jersey: Africa world Press.

Todaro, M. (1989) Economic Development in the Third World, Fourth Edition, Longman, New York \& London

Webb, Patrick. (1995) In Von Braun, Joachim. (ed) Employment for Poverty Reduction and Security, "Employment Programmes for Food Security in Rural and Urban Africa: Experiences in Niger and Zimbabwe": International Food Policy Research institute.

World Bank (2006) World Development Indicators. The World Bank: Washington D.C.

World Bank (2003) Reaching the Rural Poor. A Renewed Strategy for Rural Development. Washington D.C: The World Bank.

World Bank (2000) Can Africa Reclaim the 21 ${ }^{\text {st }}$ Century? Washington D.C: The World Bank. 